○特集 ミニシンポジウム：生体莫の研究は今?

\title{
膜機能の異常と動物の疾患
}

\author{
稲葉 睦 ${ }^{*} \cdot$ 伊東大介・大田 寛

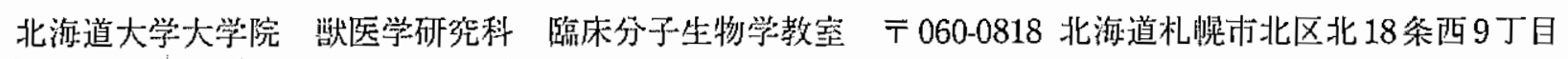

\section{Dysfunctions in Membrane Proteins and Inherited Diseases}

\author{
Mutsumi Inaba*, Daisuke Ito and Hiroshi Ohta
}

Laboratory of Molecular Medicine, Department of Veterinary Clinical Sciences, Graduate

School of Veterinary Medicine, Hoklkaido University, Sapporo 060-0818

Genetic mutations of various membrane proteins cause a variety of inherited diseases. Here we show the recent progress in molecular pathogenesis for several membrane disorders in cattie. The R664X mutation in the $A E 1$ (anion exchanger 1) gene causes hemolytic anemia associated with dominant hereditary spherocytosis. The R664X AE1 has a dominant negative effect on expression of wild-type AE1 through the endoplasmic reticulum-associated degradation (ERAD). The proteasomal degradation of R664X AE1 is independent of N-glycosylation and occurs without ubiquitination at a demonstrable level. Moreover, proteasome inhibitors do not cause aggresome formation of R664X AE1 but remarkably increase its retention in the endoplasmic reticulum, suggesting that the proteasome is required for retrotranslocation of mutant $\mathrm{AE} 1$ in addition to degradation of the mutant. These characteristics are totally different from those observed in ERAD for cystic fibrosis transmembrane conductance regulator. Recent findings on renal tubular dysplasia due to deficiency of the tight junction protein claudin-16 are also discussed.

Key words : membrane proteins / inherited diseases / $\mathrm{AE} 1 / \mathrm{ERAD} /$ proteasome / claudin

\section{1.はじめに}

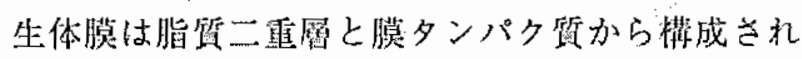
る，その機能は，多㴍な膜タンパク筑の機能と性犋 に主に依存している。償タンパク質には，脂質二雪 燐を1回，あるいは複数回買通する膜内在性タンパク 犋，糖脂啠糖鍞を分して膜外側琵面に分布するGPI 結合型タンパク貎，さらに，何らかのかたちで膜と 相互作用する米梢性の膜タンパク賢が存在する。過 去, 細胞の㯇造と機能に惪接寄与するこれら膜夕ン パク質の遗伝于の变巽が栐々な疾患の原因となって いることが知られ，遊にそれをとおして膜タンパク 筫分子の機能が次々に明らかになってきた。 Duchenne 型筋ジストロフィーの原因となるdystrophinの䍚常は，古くから知られる球状赤佔球症

\footnotetext{
* Corresponding Author

Tel \& Fax : 011-706-5580

e-mail : inazo@vetmed.hokudai.ac.jp
}

hereditary spherocytosis（HS）などの砳究と相まっ て，細胞膜を睦打ちする膜骨格の重要性を確立した。 欧米人に多い裂胞性線維症 cystic fibrosis 加，程洂亿 オンチャネルであるCFTRであることが明らかにな

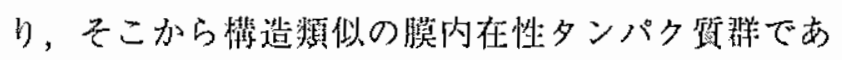
る $\mathrm{ABC}$ トランスポーターの砳究が進んだ。近年では， 水チャネル aquaporinの発胃以来，これとは一見隹関 倸な細胞運動や脨渾，ガンなどとの関連が指摘され ている。

本稿では，多桃な分子罣常と疾㭧のうち，アニオ ン交換翰送体 $\mathrm{AE} 10$ 買掌による疾患, タイトジャン クションのタンパク質 claudinの買常による疾患につ いて，著者らの動物に招ける疾患への取組を中心に 枇説する。

2. AE1の異常と ERAD, 膜トラフィック

\section{$2.1 \mathrm{AE} 1$ の遗伝子変翼と疾㭧}

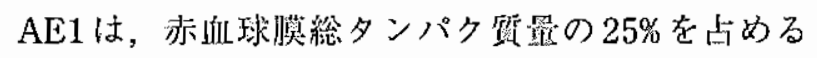


band 3 として知られる分子量的 100,000 の膜内在性夕 ンパク啠であり，膜内外で $\mathrm{Cl}^{-}$と $\mathrm{HCO}_{3}{ }^{-}$文交換輸送す るとともに，膜骨格タンパク筑を脂啠二重屡につな き止めて，膜構造を安定に維持寸る役制を果たして

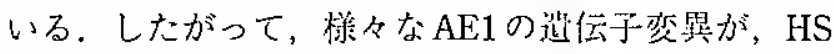
妾ともなった溶血性䟺血，または尿縕管性アアシドー シス（dRTA），あるいはその雨者を引き戈こすい。

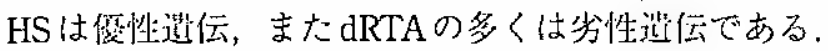

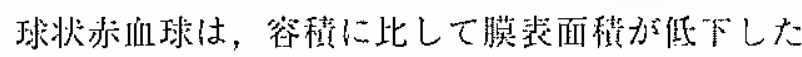
状態にある，HSに抢ける赫血球膜の裂失は，AE1含 趿の低下により膜脂翼の安定性が低下するためとさ

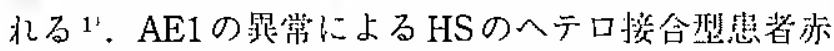
洫球（ヒトではAE1造伝子簧常によるHSのホモ愋合 型は胎生致死であり，ほとんど全てがへテロ摸合型 であるにに拈ける $\mathrm{AE} 1$ 合是は，选伝子变買によって 異なるが，正常赤血球の $50 \sim 80 \%$ に減少している。 したがって，AE1の減少に志じた赤血球膜の㖘垁が 生し，偦性のHSをもたらすと考えられる。しかし，

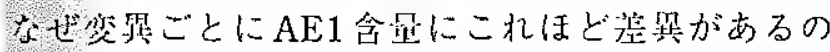
か？ AE1 ノックアウトマウスのヘテロ個体に㧍ける AE1 含早が正管の 80 - 90\%であるから2，その程度 は正篃アレル田来のAE1で䝵えるはずである。なぜ， これ以上の減少が生じ得るのか？

\section{2 变異 AE1 の分解・除去とドミナントネガテ イブ作用}

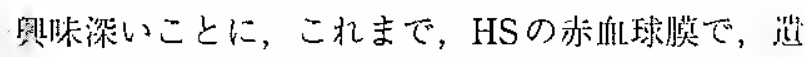
伀子変異により生じる異常な $\mathrm{AE} 1$ 分子が検出された 例はない。即ち，こ机ら買賞な分子は，たと台成 されても，赤血洯搃に分布できずに分解・除去され ていると考えら机る。

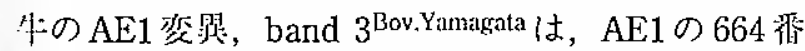

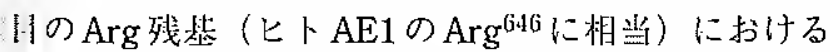

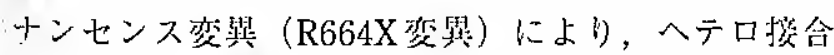
㤠ではAE1含崩が70\%に低下，また木モ㩲合型では

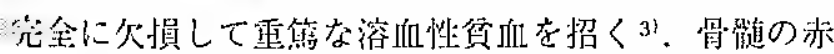
芽球系前駆細胞には桨琣アレル的涞の mRNAが充分 に存低するが，赤组球では買常分子はやはり企く检 出されない，K562，あるいは HEK293に AE1 遇伝子

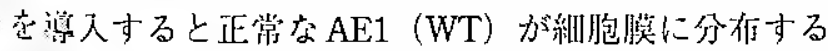
㥞甬・加钼察さ狄る。一方，R664X AE1は，小胞体 (ER)に一致した分布を示し，細胞膜には認められな い(Fig. 1)。また，合成されたR664X AE1はWTに 比べて不安定で，プロテアソーム分解系により尔解 される。WT AE1 とR664X AE1の雨者を妍入した維 胞では，而省のオリゴマー形成，WTの分解促進と膜 移行の低下が楒めら机る。即ち，R664X AE1は，WT の緋胞脱での安尘発現に対してドミナントネガティ
A
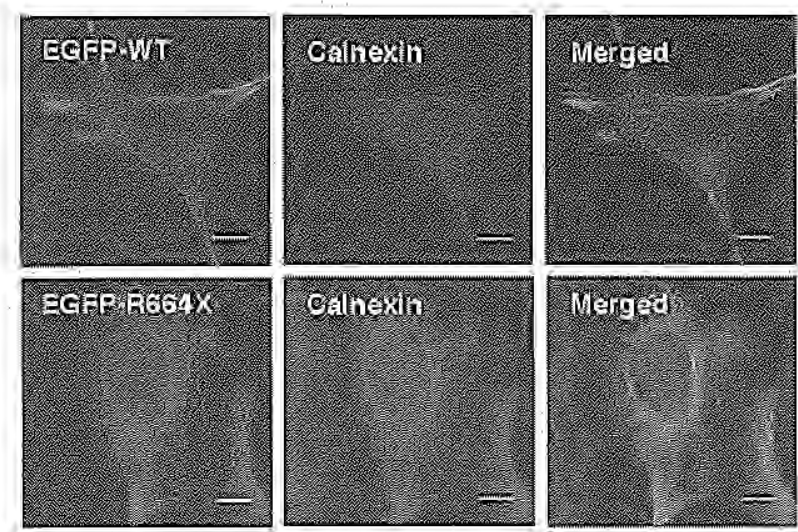

Nigigd

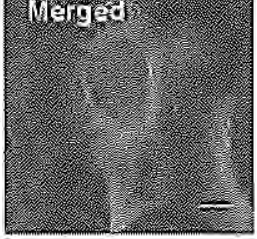

B

293bebWT
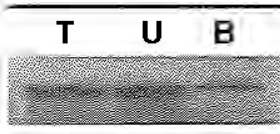

293bebRX

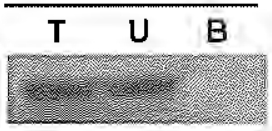

C
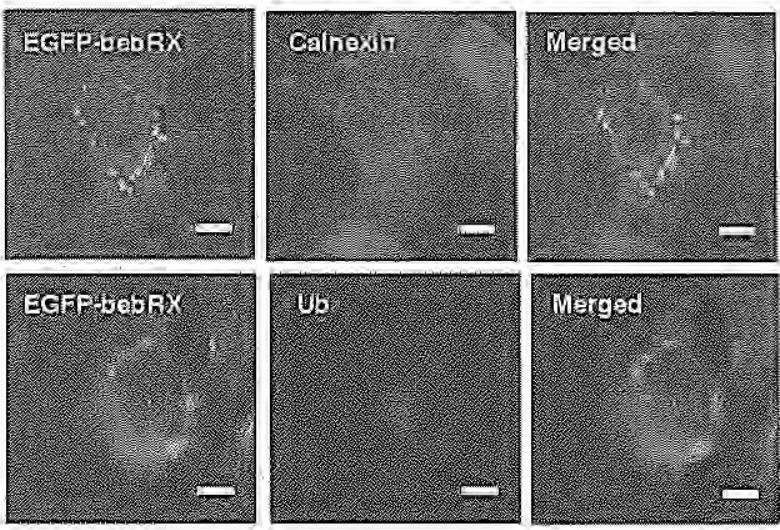

inerged

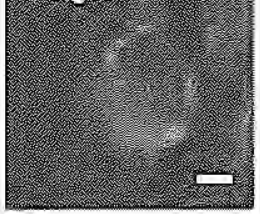

Iig. 1 Expression of WT and R664X AE1 in HEK293 cells. A, HEIK293 cells stably expressing EGFP-WT and EGFP-R664X AE1 were reacted with anti-calnexin (Calnexin) followed by detection with a secondary antibody labeled with AlexaFluor 568. Bars $=10$ $1 / \mathrm{m}$. B, cell-surface proteins in HEK293 cells transiently transfected with WT and R664X were biotinylated and polypeptides in total cell lysate $(T)$ were separated into bound (B) and unbound (U) fractions on NutrAvidin beads followed by detection of AE1 by immunoblotting. C, HEK293 cells stably expressing EGFP-R664X AE1 were incubated with $10 \mu \mathrm{M}$ lactacystin for 8 hours and intracellular localization of the mutant was compared to calnexin (upper panel) and Ub (lower panel), indicating colocalization of $\mathrm{R} 664 \mathrm{X}$ AE1 with calnexin but not with Ub. Bars $=10 \mu \mathrm{m}$.

ブに作用し，発現を低下させることがわかる。

他の $\mathrm{AE} 1$ 变珙のいくつかでも，こ机に類似した膜 移行の思第やドミナントネガティブ作用がうかがえ 
ることから，変異の種類によって程度の差舆はあれ， こうしたメカニズムが袋性のHSの病態に関わってい ると考えられる。

\section{3 膜内在性タンパク質の ERAD}

ERに扔いて合成されたタンパク質の槛造異常を䜑 識し，プロテアソーム系で分解する，いわば品犋管 理の㑡きが ERAD（ER-associated degradation）とし て知られるい．可溶性タンパク質のブロテアソームに よる分解については詳細な榆詩が行わ玌てきた。一 方, 噪内在性タンパク啠の ERADについては, 従来,

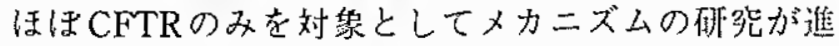
められている ${ }^{5}$ 。 その特徽のひとつは，一般的な可溶 性タンパク賢の分解と同様にコビキチン (Ub) 化を 受けた㣪に細胞犋に茞ばれてプロテアソームにより 分解さ机ること，また分解が抑制さ机た際に，緗胞 堅の中心作領域で aggresome と呼ばれる凝集地を形 成することである6.71，R664X AE1の分解が與味媣い のは，CFTRと巽なり，少なくとも枌出可能なレベル でUb化が生じず，また aggresomeの非城も微られな い点である (Ito et al., 投槁中)。プロテアソームのイ ンヒビターを作用させると，R664X AE1は光しろ ER に著しく蒛穔する（Fig. 1）ことから，プロテアソー

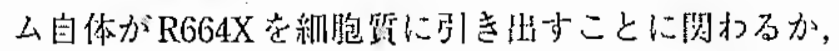
あるいはプロテアソームによる分解が ER 近修で生じ ることが推涀できる。

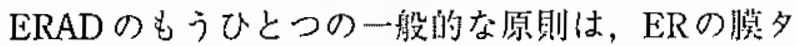

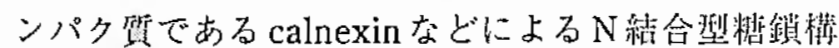
造の認諳音を受けることである、糖タンパク質である CFTRもこ扎に該当する。しかし，牛の AE1は糖顀 を持たない。したがって，R664X AE1の ERADは少 なくとも N結合型糖鎖には非依存性であるといえる。 粕鎖を持なないタンパク質と calnexinの相亚作网の

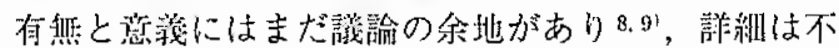
明である。

\section{$2.4 \mathrm{AE} 1$ の膜トラフィック}

R664Xをはじめ, HSやdRTAを生じる AE1変異に 関する報等10,11) 加らは，AE1の正管な細胞膜への移 行に必要な装装のひとつとして，そのC-末端領域が 重琵なことが示鄍される。この領域の悱々なアミノ

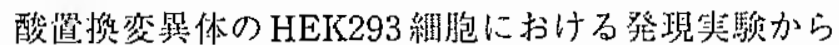
は，渄物種閣で保存されている ELXXLDADD と配列 が重要なことが考えら机る。偶然かもしれないが， aquaporin 1 の-米端にも同様の配列が存在して扔り 與味深い。またこのなかの LDADD 配列には岸酸 脱水醇装が絈合することが知られている。しかし， この配列だけで膜移行が䙺定されないことも事策で
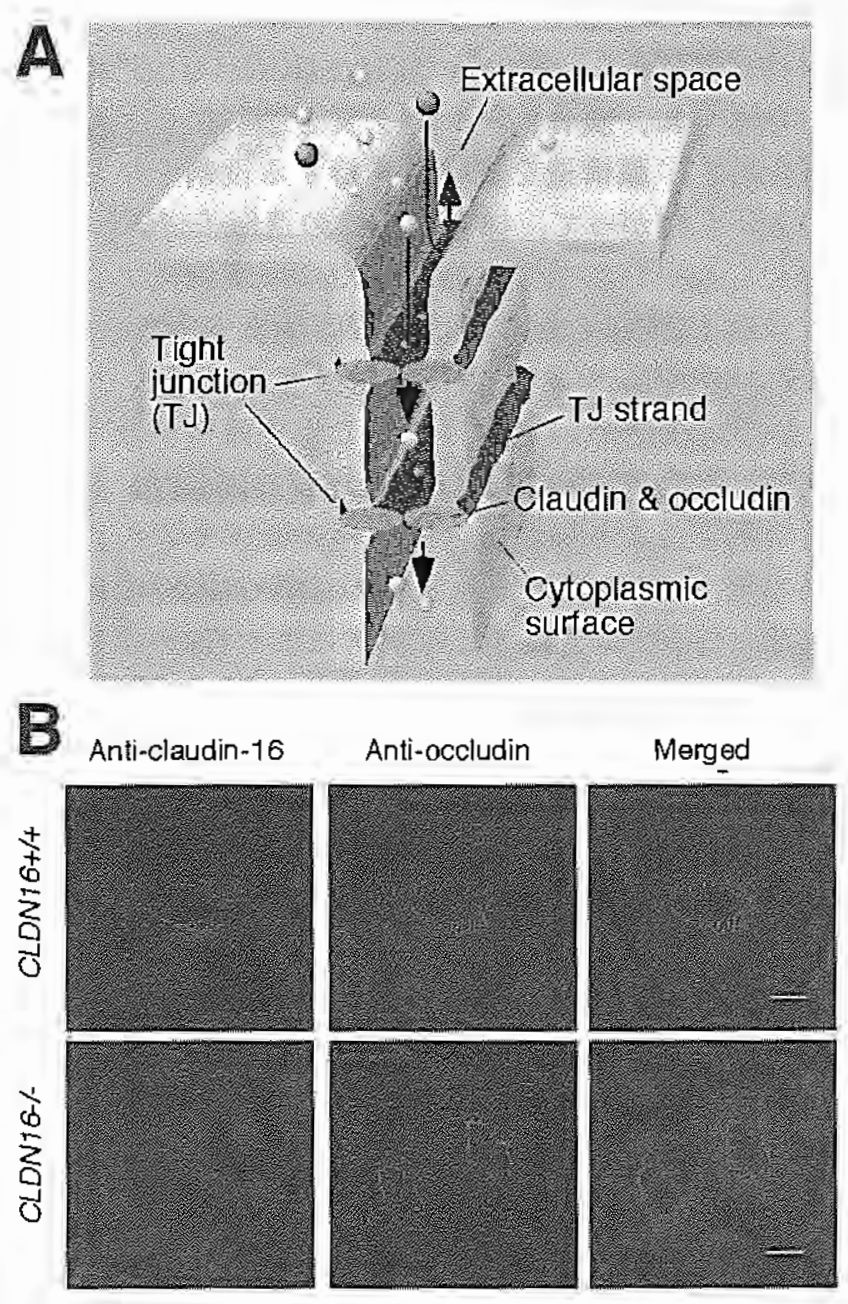

Fig. 2 Claudin-16 deficiency in cattle. A, schematic illustration for the structure and function of the $\mathrm{TJ}$ consisting of transmembrane proteins occludin and claudins. B, immunohistochemical detection of claudin-16 at the $\mathrm{TJ}$, indicated by colocalization with occludin, in developing renal tubules of $C L D N 16^{+/+}$ and $C L D N 16^{-/-}$fetuses at 100 days of gestation. The representative tubules in $C L D N 16^{-/-}$fetus shows clearly stained occludin at the apicalmost region, suggesting the formation of the $\mathrm{TJ}$ structure even in the absence of claudin-16. These tubules were confirmed to be positive for Tamm-Horsfall glycoprotein, a marker for the thick ascending limb of Henle's loop, in the serial frozen sections.

ある。なぜならば，ERに止まり膜移行しない变異体

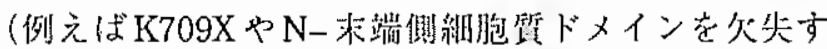

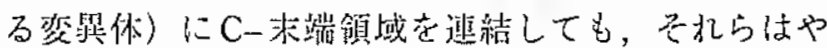
はり膜移行を生じないからである。この ELXX LDADD 配列が，AE1 分子内の他の領域と相互作羽す ることが重夏と思狆机が解测には至っていない。 


\section{3. クローディンー16の次損と尿細管形成 巽常}

\section{1 クローディン遺伝子の暴常と疾患}

クローディン claudin 分子群は，上皮細胞間のタイ トジャンクション（TJ）を構成する主要な膜内在性 タンパク啠である。現在，20を迢える遗伝子ファミ リーであり，それぞれが茂器や組織に特買的な分布 を示す。その役制は，TJに扔ける細胞間接摜と細胞 間の堅択的な物質輸送（傍細胞輸送）のためのバリ ア機能である12１3）（Fig. 2)。現在のところ，自然発症 の疾腎で巽常が知られるのは, claudin-14の变異によ

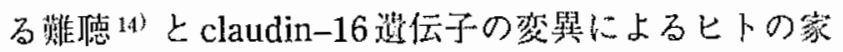
族性低マグネシウム血症富カルシウム尿症 (FHHNC) 15! と牛の腎尿細管形成不全 ${ }^{16 !}$ に留まるが，今後，多 くの疾隐との関逃が見出されると思われる。

牛の尿細管形成不全は, claudin-16遗伝子の欠头に よって生じ，若督命で尿細管の菼縮や低形成，間澌性 督炎がみられ，腎不全が淮行して多くは死に至る。

\subsection{Claudin-16 欠損症：尿細管形成不全はなぜ} 生じるか?

ヒトのFHHNCでは，尿細管における $\mathrm{Mg}^{2+}$ と $\mathrm{Ca}^{2+}$ の再吸収不全が主たる徽候であり，この病態に基づ है, claudin-16は $\mathrm{Mg}^{2+}$ と $\mathrm{Ca}^{2+}$ を選択的に通す TJ を形 成することが明らかになった，牛では尿細管の㮐造 累常が顕著である一方， $\mathrm{Mg}^{2+}$ と $\mathrm{Ca}^{2+}$ の代謝には大き な買常がみられず，代償作用の存在がうがえる。 牛でもヒトやマウスと同倳に claudin-16は尿細管 Henleの太い上行挪（TAL）部分に限局して分布する (Ohta et al., 投稿㠶。若踰の牛個体で尿細管形成に 買常が認められることから， claudin-16が細胞間接着 を介して尿細管形成に重要な役割をもつことが期街 されたため, claudin-16遗伝子欠損 (CLDN16-/-) と 判定した受精卵を仮母物に移植し，胎子期における 㫰細管形成解析を試みた。しかし，予想に反し，胎 䉖100，180，そして出生間近の270日のいずれにお オても，CLDN16 のそれと同等であり，TALを含め，組緁溙造形成は ほほ正常であった。ただし，同部位における他の claudin 分子の登現に変化が喼められ, claudin-16の 久椇と僻せ，T丁機能に変化が生じることが想定され る. (Ohta et al., 投稿中). したがって, claudin-16が 単独で尿細管の分化や形成に必須の機能を持つこと は否定的である，尿細管の篓繀等の異常は，出生後，

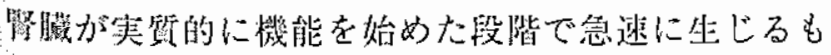
のと思扎れる。そ机には，本来， claudin-16が存在す
る領域におけるTJのバリア機能, 即ち選択的な傍絸 胞輸送の買常が関わるものと推测される。

Claudin-14の変罪による難聴では，TJに扔ける $\mathrm{Na}^{+}$透過を阻む claudin-14の機能の異常によって，コ ルチ器官の細胞が膜電位を保てなくなり崩塯すると される.Claudin-16 欠損症でも，同棁のメカニズム

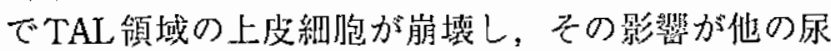
細管領域にも波及寸ることが考えられる。

\subsection{TJにおける claudinの機能：接着か，透} 過か?

䇟り合う細胞間のTJで， claudin 分子同士がどのよ うに相互作用して，細胞間を接者し，あるいは物貿 透過の孔を此成しているのかはまだ不明である。上 記のように, claudin-16や claudin-14の暴常の場合， 疾腎発症の采口は，それらの分子の物筫透過に関わ る機能の貲常にあり，接着における単独での役割は 少ない上うに思われる。おそらくは，他の claudin 分 子が共在する組㵶であるために，縕胞間摸着は他の 分子が代儥しているのであ万う。一方, claudin-11の ノックアウトマウスは，叫枢神経ミエリンのTJ㭢造 完完金に失い，神経症状を呈する ${ }^{17}$ 。単独の claudin で椎成されるて丁に扔いては，その発現は必須のもの で，occludinなど他のTJ檏成タンパク質では補えな いのであろう。

\section{4. まとめ}

変異膜タンパク質に関する若下の知見を述べた。 タンパク筫のフォールディングや分解，細胞内輸送 のメカニズムは，現在の生体膜硎究のなかでも大き な割合を占めているが，模内在性タンパク貿につい ては端緒に着いたばかりといえる。当たり前のこと だが，生体膜分子の期きや変化を確かに捕まえるこ とがますます重要となる。

ヒトや動物のゲノム解衍が進み，橡々なゲノムマ 一カーが利用できる現在では，特定の単一遗伝子の 簧常に起因する疾患について原因选伝子翼常を同定 すること自体は恃間と学力を要するものの比較的容 易である，本留的に雪要なのは，只の原因遗伝子の 異常加，生体膜分子の機能や他の分子との相互作 用，それらの細胞・生体活秒への寄与を明らかにす ることであ万う。この意味で，ヒト，䀦物を問わず， 疾患の病態に関する基礁知見は，現在も，そして今 後も，膜タンパク啠機能の解明に，さらには疾䁅の 予防や治潦にも，重哭な役割を果たすはずである。 


\section{文献}

1) Tse WT, Lux SE : Hereditary spherocytosis and hereditary elliptocytosis. In The metabolic \& molecular bases of inherited disease, 8th ed. (ed. Scriver $\mathrm{CR}$, Beaudet AL, Sly WS and Valle D), pp. 4665-4727, New York, McGraw-Hill (2001)

2) Peters LL, Shivdasani RA, Liu S-C, Hanspal M, John KM, Gonzalez JM Brugnara C, Gwynn B, Mohandas N, Alper SL, Orkin SH, Lux SE : Cell, 86, 917-927 (1996)

3) Inaba $M$, Yawata $A$, Koshino I, Sato $K$, Takeuchi $M$, Takakuwa Y, Manno S, Yawata Y, Kanzaki A, Sakai J, Ban A, Ono K, Maede Y :J. Clin. Invest., 97, 1804-1817 (1996)

4) Ellgaard L, Helenius A : Nat. Rev. Mol. Cell Biol., 4, 181191 (2003)

5) Ward CW, Omura S, Kopito RR : Cell, 83, 121-127 (1995)

6) Johnston JA, Ward CL, Kopito RR : J.Cell Biol., 143, 18831898 (1998)

7) Gelman MS, Kannegaard ES, Kopito RR : J. Biol. Chem., 277, 11709-11714 (2002)

8) Danilczyk UG, Williams DB : J. Biol. Chem., 276, 2553225540 (2001)

9) Farinha CM, Amaral MD : Mol. Cell. Biol., 25, 5242-5252 (2005)

10) Toye AM, Bruce LJ, Unwin RJ, Wrong O, Tanner MJA : Blood, 99, 342-347 (2002)

11) Toye AM, Banting G, Tanner MJA : J. Cell Sci., 117, 13991410 (2003)

12) Tsukita S, Furuse M, Itoh M : Nat. Rev. Mol. Cell. Biol., 2, 285-293 (2001)

13) Van Itallie CM, Anderson JM : Physiology, 19, 331-338 (2004)

14) Wilcox ER, Burton $Q L, N a z S$, Riazuddin S, Smith TN, Ploplis B, Belyantseva I, Ben-Yosef T, Liburd NA, Morell RJ, Kachar B, Wu DK, Griffith AJ, Riazuddin S, Friedman TB : Cell, 104, 165-172 (2001)

15) Simon DB, Lu Y, Choate KA, Velazquez H, Al-Sabban E, Praga M, Casari G, Bettinelli A, Colussi G, RodriguezSoriano J, McCredie D, Milford D, Sanjad S, Lifton RP : Science, 285, 103-106 (1999)
16) Ohba $Y$, Kitagawa $H$, Kitoh $K$, Sasaki $Y$, Takami M, Shinkai Y, Kunieda T : Genomics, 68, 229-236 (2000)

17) Gow A, Southwood CM, Li JS, Pariali M, Riordan GP, Brodie SE, Danias J, Bronstein JM, Kachar B, Lazzarini RA : Cell, 99, 649-659 (2004)

(Received 25 September 2005; Accepted 27 September 2005)

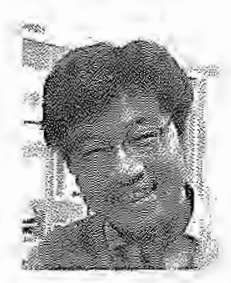
著诸略歴

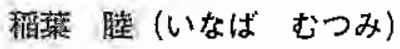
1982年3月北海道大学獸医学郘 离䔩

1984 年3月＼cjkstart北海道大学大学院狱医 学研究科修与課程修了

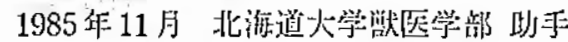
1988年11月 同嚁阿 1990 年 4 月 1991作3月 Rush Presbyterian St. Luke's Medical Center (シカゴ) 留学

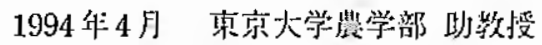

1997 年 4 月 身京大学大学院崖学生余利学研觉科助数授

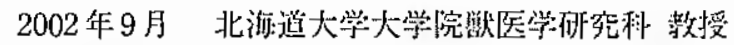

現在に珰る

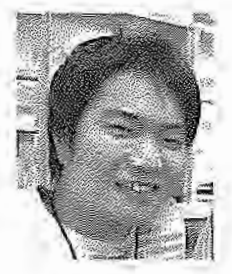

本 大介（いとう だいすけ）

2002 年3月北湤道大学哭医学郘卒 桨

2002 年 4 月 北游道大学大学院㼳医 学版究科愽上課程入学

2003 作 4 月日本学術振興会特別研 究置

現在に至る

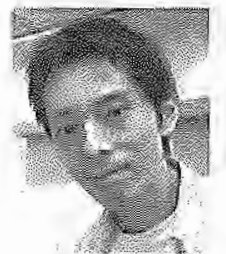

大田 骞(おおた ひろし)

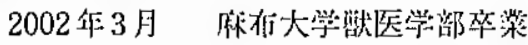

2002华4月北海道大学大学院㴊医 学研究科博士㒛程入学

現在に至る 